\title{
Primary resistance of human immunodeficiency virus type 1 in a reference center in Recife, Pernambuco, Brazil
}

\author{
Luzidalva Barbosa de Medeiros/**, Heloísa Ramos Lacerda/*/**/+, \\ Ana Maria Salustiano Cavalcanti***, Maria de Fátima Pessoa Militão de Albuquerque/****
}

\author{
Hospital das Clínicas *Pós-Graduação em Medicina Tropical **Departamento de Medicina Clínica, Universidade Federal de \\ Pernambuco, Av. Moraes Rego, s/nº, Cidade Universitária, 50670-420 Recife, PE, Brasil ***Laboratório Central, Secretaria \\ Estadual de Saúde de Pernambuco, Recife, PE, Brasil
}

To assess the prevalence of primary resistance of human immunodeficiency virus type 1 (HIV-1) to antiretrovirals, 84 patients chronically infected with HIV without prior antiretroviral treatment from Northeast Brazil were studied. Genotyping was performed using the ViroSeq ${ }^{T M}$ Genotyping System. Thimidine analog mutations occurred in 3 (3.6\%) patients. Accessory mutations related to NRTI occurred in $6(7.1 \%)$ and related to PI in 67 (79.8\%). Subtypes B (72.6\%), $F(22.6 \%), B / F 3(3.6 \%)$, and $C(1.2 \%)$ were detected. A low prevalence of major mutations related to NRTI in patients chronically infected by HIV was observed.

Key words: human imunodeficiency virus type 1 - primary resistance to drugs - genotyping - subtypes - Brazil

Highly active antiretroviral therapy (HAART) has modified the course of the acquired immunodeficiency syndrome (AIDS) and prolonged the life of its victims (Palella et al. 1998, Mocroft et al. 2003). However, failure of HAART has been reported, attributed to several factors, resistance to drugs being the most important (Hanna \& D'Aquilla 1999). When the resistance occurs without the prior use of antiretrovirals, it constitutes the primary resistance and is generally transmitted at the time of acquisition of the viral infection (Boden et al. 1999). The problem becomes even more serious when one notes that the resistance to two or more classes of drugs can also be transmitted in primary infections (DeGruttola et al. 2000, Tamalet et al. 2000, Little et al. 2002).

The genotyping resistance assay allows the mapping of regions with a high prevalence of primary resistance, where the genotyping test performed in patients without prior treatment would be indicated and would help to determine the initial drugs of choice for empirical treatment (Hirsch et al. 2003).

The universal provision of medication by the Brazilian Ministry of Health, which began in 1996 dramatically changed the mortality related to AIDS in Brazil (Marins et al. 2003). However the massive use of these medications brings the risk of resistance (Clavel \& Hance 2004), which must be continuously monitored.

In this paper we describe the prevalence of primary resistance of HIV-1 in individuals without previous treatment attending a reference health center for HIV/AIDS in Recife.

Financial support: National Program of STD/AIDS, Brazilian Ministry of Health

${ }^{+}$Corresponding author: helramos@terra.com.br

Received 15 February 2006

Accepted 20 September 2006

\section{MATERIALS AND METHODS}

Cases - A total of 101 individuals infected by HIV-1 in consecutive attendance at the Federal University of Pernambuco Hospital in Recife, between February 2002 and January 2003, were studied. None of them had used antiretrovirals previously. The participants received the relevant information and signed the consent form. The study was approved by the Ethics Commission of the University's Health Sciences Center (Protocol no. 158/ 2001-CEP/CCS).

HIV-1 resistance genotyping determination - The ViroSeq ${ }^{\mathrm{TM}}$ HIV-1 Genotyping System (Celera Diagnostic, Abbott Laboratories, US) was used to identify the resistance-associated mutations in the HIV-1 polymerase (pol) gene. The methodology included the isolation and purification of plasma viral RNA followed by cDNA synthesis and genomic amplification by polymerase chain reaction (PCR) assay of the HIV-1 pol fragment (RT-PCR and PCR module), spanning the entire protease (PR) gene and approximately two thirds of the RT gene. The amplified PCR products were sequenced using the BigDye Terminator sequencing chemistry (Sequencing Module - Big Dye v.2.0) and analyzed on an ABI Prism ABI 3100 Genetic Analyzer (Applied Biosystems, US) coupled to the DNA sequencing analysis software. Mutations resistance profiles were classified according to the International AIDS Society US consensus (D'Aquilla et al. 2002). For the determination of the genetic subtypes of the HIV-1 all sequences were analyzed using the Stanford Sequence Resistance Database (http://hivdb.stanford.edu).

\section{RESULTS}

A total of 101 patients had their blood samples collected. Seventeen $(16.8 \%)$ of the samples were excluded because they did not generate fragments in the PCR for the region of reverse transcriptase or protease. The remaining 84 patients have their data described in this paper. 
Most of patients were men (64.3\%), aged 18-40 years $(67.9 \%)$, with up to 8 years of formal education (64.4\%). The mode of transmission of HIV-1 infection was mostly sexual. Heterosexual practices $(58.2 \%)$ were detected in the majority of cases, followed by homosexual ones $(41.8 \%)$. Transmission through IV drugs or blood transfusion occurred in just $3(3.5 \%)$ patients. The mean CD4 lymphocyte count was 178.7 cells $/ \mathrm{mm}^{3}$; the mean viral load was 269,305 copies $\mathrm{RNA} / \mathrm{ml}$ and the majority of patients were symptomatic $(90.5 \%)$.

Three samples (3.6\%) showed primary mutations related to NRTI (all of them Thymidine Analog MutationsTAMs) as follows: $2(2.4 \%) \mathrm{M} 41 \mathrm{~L}$ and $1(1.2 \%) \mathrm{K} 219 \mathrm{E}$ (Table). No primary mutations related to NNRTI or PI were detected.

Accessory mutations related to reduced sensitivity to commonly used NRTI or NNRTI (TAM-associated mutations) occurred in the positions V118I in 5/84 (5.9\%) and E44D in 1/84 (1.2\%) patient.

Minor mutations related to PI occurred in 67 (79.8\%) sequences of the PR gene in the following positions: L63P in 40/84 (47.6\%), M36I in 29/84 (34.5\%), L10I/V in 14 (16.7\%), V77I in 13/84 (15.5\%), K20R in 9/84 (10.7\%), A71T/V in 8/84 (9.5\%) and I54P in 1/84 (1.2\%) patient (Table). Nine samples (10.7\%) presented mutations related to NRTI and IP simultaneously.

Subtype B was detected in 61 patients (72.6\%), F in 19 (22.6\%), and B/F in 3 (3.6\%). Subtype C occurred in one patient $(1.2 \%)$, who had arrived recently from the Southeast region of Brazil.

\section{DISCUSSION}

This study revealed a low prevalence of primary mutations of resistance related to NRTI in individuals chronically infected without previous treatment.

A major criticism of the study is that it analyzes primary resistance in chronically infected individuals. One can argue that, in these patients, the acquisition of the infection must have happened several years before and the mutations of resistance would no longer be detected in the absence of the drug selection pressure (Clavel \& Hance 2004). That is actually true in patients with secondary resistance (Diaz 2004); however, several studies have demonstrated the persistence of mutations of primary resistance for periods as long as five or seven years (Brenner et al. 2002, 2004, Barbour et al. 2004, Pao et al. 2004), supporting the rationale for testing the chronically infected (Novak et al. 2005).

The three cases (3\%) of major mutations found in the present study were TAMs, which lead to resistance to the majority of NRTI, especially zidovudine and stavudine. NRTI was the first group of antiretrovirals introduced into clinical use; one could therefore infer that these viruses represent the circulating virus at the time of infection acquisition, probably several years ago. While considered to be of minor importance, the following other mutations should be noted: the E44D mutation, which commonly accompanies the TAMs and, when associated with V118I or TAMs, causes low-level resistance to lamivudine and other NRTI (Montes \& Secondy 2002, Houtte et al 2003); the A71I mutation, which occurs in 5 to $10 \%$ of untreated

TABLE

Age, sex, risk behavior, subtypes, and mutations associated with nucleoside reverse-transcriptase inhibitors (NRTI), nonnucleoside reverse-transcriptase inhibitors (NNRTI), and protease inhibitors (PI)

\begin{tabular}{|c|c|c|c|c|c|c|c|}
\hline \multirow[b]{2}{*}{ Code } & \multirow[b]{2}{*}{ Age } & \multirow[b]{2}{*}{ Sex } & \multirow[b]{2}{*}{ Risk behavior } & \multirow[b]{2}{*}{ Subtype } & \multicolumn{3}{|c|}{ ARV classes } \\
\hline & & & & & NRTI & NNRTI & PI \\
\hline $\mathrm{AAB}$ & 25 & M & MSM & B & & & L63P, A71V, V77I \\
\hline AAS & 50 & M & HTS & $\mathrm{B}$ & & & M36I \\
\hline ALMR & 24 & M & HTS & B & & & \\
\hline ALS & 24 & M & MSM & B & & & V77I \\
\hline AMAS & 56 & $\mathrm{~F}$ & HTS, HEM & $\mathrm{F}$ & & & \\
\hline AMLF & 35 & $\mathrm{~F}$ & HTS & $\mathrm{F}$ & & & M36I \\
\hline APS & 22 & $\mathrm{~F}$ & HTS & B & & & L10I, L63P \\
\hline ARC & 22 & M & MSM & $\mathrm{B}$ & & & V77I \\
\hline CBB & 32 & M & HTS & $\mathrm{B}$ & & & L63P \\
\hline CBS & 59 & M & HTS & B & & & L63P, M36I \\
\hline DCB & 80 & $\mathrm{~F}$ & HTS & B & & & L10I, A71T, L63P, V77I \\
\hline DSBM & 39 & M & MSM & $\mathrm{B}$ & & & L63P \\
\hline EAE & 37 & M & MSM & $\mathrm{BF}$ & & & M36I \\
\hline EAM & 45 & $\mathrm{~F}$ & HTS & $\mathrm{B}$ & & & V77I \\
\hline EAS & 31 & M & MSM, IVDU & B & & & \\
\hline EAS & 35 & M & MSM & $\mathrm{F}$ & & & K20R, M36I \\
\hline $\mathrm{ECC}$ & 38 & M & HTS & B & & & L63P \\
\hline ECS & 41 & M & HTS & B & & & L63P \\
\hline $\mathrm{EF}$ & 49 & M & HTS & B & & & \\
\hline EJO & 29 & M & MSM & B & & & M36I, L63P \\
\hline EJS & 54 & $\mathrm{~F}$ & HTS & B & & & L63P \\
\hline EMS & 35 & M & MSM, IVDU & B & & & M36I, L63P \\
\hline
\end{tabular}




\begin{tabular}{|c|c|c|c|c|c|c|}
\hline ERRO & 20 & $\mathrm{~F}$ & HTS & B & & \\
\hline ESA & 35 & M & MSM & B & & L63P, A71T \\
\hline ESB & 21 & $\mathrm{~F}$ & HTS & $\mathrm{F}$ & & K20R, M36I \\
\hline ESC & 31 & $\mathrm{~F}$ & HTS & $\mathrm{F}$ & & K20R, M36I \\
\hline FAS & 32 & M & HTS & $\mathrm{F}$ & & M36I \\
\hline FAS & 33 & $\mathrm{M}$ & HTS & $\mathrm{F}$ & & L10V, M36I \\
\hline FFS & 43 & M & MSM & $\mathrm{BF}$ & & M36I \\
\hline GL & 29 & M & MSM & B & & M36I \\
\hline HSB & 50 & M & HTS & B & & \\
\hline ICMS & 33 & $\mathrm{~F}$ & HTS & B & & \\
\hline IFG & 36 & M & MSM & B & & \\
\hline JBS & 43 & M & MSM & B & & L63P, A71V \\
\hline JBV & 46 & $\mathrm{~F}$ & HTS & B & & I54P, L63P \\
\hline JCES & 45 & M & MSM & B & & \\
\hline $\mathrm{JCL}$ & 30 & $\mathrm{M}$ & MSM & B & & L63P \\
\hline $\mathrm{JCS}$ & 41 & $\mathrm{~F}$ & HTS & B & & L63P \\
\hline JCSN & 19 & $\mathrm{M}$ & HTS & $\mathrm{F}$ & & K20R, M36I \\
\hline JDP & 36 & M & MSM & $\mathrm{F}$ & & K20R, M36I \\
\hline JDSL & 28 & $\mathrm{~F}$ & HTS & $\mathrm{F}$ & E44D & M36I \\
\hline JFS & 31 & M & MSM & $\mathrm{F}$ & V118I & M36I, L10V \\
\hline JGS & 45 & M & MSM & B & & L63P \\
\hline JJS & 31 & M & HTS & B & & L63P, A71T \\
\hline JLA & 27 & M & MSM & B & & V77I, L63P \\
\hline JLN & 41 & M & MSM & B & & \\
\hline JMC & 66 & $\mathrm{M}$ & HTS & B & & \\
\hline JRS & 37 & M & MSM & B & & L63P \\
\hline JSM & 42 & $\mathrm{~F}$ & HTS & B & V118I & M36I, L63P \\
\hline JSPN & 49 & M & HTS & $\mathrm{F}$ & & M36I, L63P \\
\hline JSS & 39 & M & HTS & B & & V77I \\
\hline LGS & 33 & $\mathrm{~F}$ & HTS & B & V118I & \\
\hline LHSP & 29 & M & MSM & B & & L63P, V77I \\
\hline LJNM & 27 & M & HTS & B & & \\
\hline LMM & 43 & M & MSM & B & & L63P \\
\hline $\mathrm{MCA}$ & 19 & $\mathrm{~F}$ & HTS & B & & L63P, V77I \\
\hline MCFS & 41 & $\mathrm{~F}$ & HTS & $\mathrm{C}$ & & M36I \\
\hline MCL & 48 & M & MSM & B & & L63P \\
\hline MCS & 35 & $\mathrm{~F}$ & HTS & B & & M36I, V77I \\
\hline MGPA & 33 & $\mathrm{~F}$ & HTS & B & & \\
\hline MIL & 36 & M & HTS & B & & L10V, V77I \\
\hline MJC & 36 & M & MSM & B & V118I & L63P, A71T, V77I \\
\hline MJOP & 20 & M & MSM & $\mathrm{B}$ & & L63P \\
\hline MJS & 23 & $\mathrm{~F}$ & HTS & B & & L63P \\
\hline MJSF & 42 & M & MSM & B & & \\
\hline MSGS & 18 & $\mathrm{~F}$ & HTS & $\mathrm{F}$ & & K20R, M36I \\
\hline MVGRN & 29 & $\mathrm{~F}$ & HTS & B & & K20R, L63P, A71T \\
\hline MEMS & 61 & $\mathrm{~F}$ & HTS & $\mathrm{F}$ & & L10V, K20R, M36I \\
\hline $\mathrm{PBC}$ & 34 & M & MSM & $\mathrm{B}$ & & L63P \\
\hline PPS & 29 & $\mathrm{~F}$ & HTS & B & & L63P \\
\hline RAR & 39 & M & MSM & B & & L63P \\
\hline RFO & 38 & M & MSM & B & & L10V, L63P, A71T \\
\hline ROSC & 24 & $\mathrm{~F}$ & HTS & $\mathrm{F}$ & & M36I, L63P \\
\hline RSF & 33 & M & MSM & $\mathrm{F}$ & & M36I \\
\hline SAF & 36 & $\mathrm{~F}$ & HTS & B & M41L & L10I, L63P \\
\hline $\mathrm{SCB}$ & 41 & $\mathrm{~F}$ & HTS & $\mathrm{B}$ & & \\
\hline SGL & 30 & M & HTS & $\mathrm{B}$ & & \\
\hline SMS & 42 & M & HTS & $\mathrm{F}$ & & L10V, M36I, L63P \\
\hline SSI & 34 & M & MSM & $\mathrm{B}$ & & L10V, L63P \\
\hline SVCS & 35 & M & MSM & $\mathrm{BF}$ & V118I & L10V, A77I, L63P \\
\hline SVNC & 39 & $\mathrm{~F}$ & HTS & $\mathrm{F}$ & M41L & L10I, M36I \\
\hline VESA & 27 & $\mathrm{~F}$ & HTS & $\mathrm{B}$ & & L10I \\
\hline VJCL & 31 & M & MSM & $\mathrm{B}$ & & M36I, L63P \\
\hline VTS & 46 & $\mathrm{~F}$ & HTS & $\mathrm{F}$ & K219E & L10V, M36I, K20R \\
\hline
\end{tabular}

MSM: men who have sex with men; HTS: heterosexual; HEM: hemophiliac; IVDU: IV drug user. 
persons with the subtype $\mathrm{B}$, but increases dramatically by as much as 60 to $80 \%$ in heavily treated patients (Hertogs et al. 2000, Wu et al. 2003); the V77I mutation, which is specifically associated with the use of nelfinavir (Wu et al. 2003); and the mutation K20R, which occurs at higher rates in subtype $\mathrm{F}$ than in subtype $\mathrm{B}$ isolates (Gonzales et al. 2001). It should not be overlooked that the concomitant occurrence of mutations related to NRTI and PI was found in $10.7 \%$ of the samples. Moreover a high frequency of minor mutations related to PI has been detected, mutations that seem to play a major role in the viral fitness recovery but have only a small impact on resistance (Diaz 2004).

Between 1996 and 1998 Brazilian investigators conducted limited regional surveys on HIV primary drug resistance that revealed rates of 0 to $9.3 \%$ of resistance (Brindeiro et al. 1999, Dumans et al. 2002). In 2003, a study that comprised 535 chronically infected individuals from all Brazilian regions showed a frequency of $6.6 \%$ of resistance to antiretrovirals (Brindeiro et al. 2003). Furthermore, Eyer-Silva and Morgado (2005), studying 27 individuals chronically infected in a small municipality of the state of Rio de Janeiro, detected no mutations related to resistance. All these data, in conjunction with the findings of this study, suggest that Brazil has lower rates of resistance to antiretrovirals than Europe and the US (Little et al. 2002, Eiros et al. 2004, Novak et al. 2005) and that in the Northeast region, particularly in Pernambuco, these rates are also very low. One might suspect, albeit without conclusive evidence, that this lower frequency of primary resistance in Pernambuco and in the Northeast as a whole is due to a later access to medication. However studies point to a worrying trend. In 2006, a study that comprised 341 blood donors from São Paulo from 1998 to 2002 revealed rates of $5 \%$ of resistance to antiretrovirals in long-standing infections and higher rates of $12.7 \%$ in the recently-infected individuals, and this difference was significant (Barreto et al. 2006). Two other studies also point to rising rates of resistance in the Southern region of Brazil. The first of these investigated 56 military personnel, and revealed $14 \%$ of NRTI associated mutations in the chronically infected patients (Pires et al. 2004). The second one, conducted in Santos in 2001 (the first Brazilian city where antiretrovirals were supplied through the public health service), showed $36 \%$ of resistance to antiretrovirals in recently-infected individuals (Caseiro 2001). One may infer that this trend probably applies also to new infections in the Northeast region.

This study confirms subtype B as the most prevalent, with subtype $\mathrm{F}$ as the second most important, as described elsewhere (Brindeiro et al. 2003). It also shows the circulation of the $\mathrm{B} / \mathrm{F}$ recombinants and the rarity of subtype $\mathrm{C}$ in this region.

\section{REFERENCES}

Barbour JD, Hecht FM, Wrin T, Liegler TJ, Ramstead CA, Busch MP, Segal MR, Petropoulos CJ, Grant RM 2004. Persistence of primary drug resistance among recently HIV1 infected adults. AIDS 18: 1683-1693.

Barreto CC, Nishyia A, Araujo LV, Ferreira JE, Bush MP, Sabino EC 2006. Trends in antiretroviral drug resistance and clade distributions among HIV-1 infected blood donors in São Paulo, Brazil. J Acquir Immune Defic Syndr 41: 338-341.

Boden D, Hurley A, Zhang L, Cao Y, Guo Y, Jones E, Tsay J, Ip J, Farthing C, Limoli K, Parkin N, Markowitz M 1999. HIV-1 drug resistance in newly infected individuals. JAMA 282: 1135-1141.

Brenner B, Routy JP, Petrella M, Moisi D, Oliveira M, Detorio M, Spira B, Essabag V, Conway B, Lalonde R, Sekaly RP, Wainberg M 2002. Persistence and fitness of multidrugresistant human immunodeficiency virus type 1 acquired in primary infection. J Virol 76: 1753-1761.

Brenner B, Routy JP, Quan Y, Moisi D, Oliveira M, Turner D, Wainberg MA; Co-investigators of the Quebec Primary Infection Study 2004. Persistence of multidrug-resistant HIV1 in primary infection leading to superinfection. AIDS 18: 2107.

Brindeiro RM, Diaz RS, Sabino EC, Morgado MG, Pires IL, Brigido L, Dantas MC, Barreira D, Teixeira PR, Tanuri A and the Brazilian Network for Drug Resistance Surveillance 2003. Brazilian network for HIV drug resistance surveillance (HIV-BResNet): a survey of chronically infected individuals. AIDS 17: 1063-1069.

Brindeiro R, Vanderborght B, Caride E, Correa L, Oravec RM, Berro O, Stuvier L, Tanuri A 1999. Sequence diversity of the reverse transcriptase of human immunodeficiency virus type 1 from untreated Brazilian individuals. Antimicrob Agents Chemother 43: 1674-1680.

Caseiro MM 2001. Prevalence and Incidence of HIV-1 Infection from 1995 to 2000 and Primary Genotypic Resistance to Antiretrovirals in a Center of Anonymous Tests for HIV1 on District of Santos, Thesis, Universidade Federal de São Paulo, São Paulo.

Clavel F, Hance AJ 2004. HIV drug resistance. $N$ Eng $J$ Med 350: $1023-35$.

D'Aquilla RT, Schapiro JM, Brun-Vézinet F, Clotet B, Conway B, Demeter LM, Grant RM, Johnson VA, Kuritzes DR, Loveday C, Shafer RW, Richmann DD, International AIDS Society-USA 2002. Drug resistance mutations in HIV-1. Top HIV Med 10: 21-25.

DeGruttolla V, Dix L, D’Áquila R 2000. The relation between baseline HIV drug resistance and response to antiretroviral therapy - Re-analysis of retrospective and prospective studies using a standardized data analysis plan. Antivir Ther 5: 41-8.

Diaz R 2004. Guia para o Manuseio de Testes de Resistência Anti-retroviral no Paciente Infectado pelo HIV-1, Ed. São Paulo, São Paulo, 88 pp.

Dumans AT, Soares MA, Pieniazek D, Kalish M, De Vroey V, Hertogs K, Tanuri A 2002. Prevalence of protease and reverse transcriptase drug resistance mutations over time in drug-naive HIV-1 positive individuals in Rio de Janeiro, Brazil. Antimicrob Agents Chemother 46: 3075-3079.

Eiros JM, Blanco R, Labayru C, Hernández B, Bou G, Dominguez-Gil M, Ortiz de Lejarazu R 2004. Rev Esp Quimioterap 17: 250-256.

Eyer-Silva WA, Morgado MG 2005. A genotyping study of human immunodeficiency vírus type- 1 drug resistance in a small Brazilian municipality. Mem Inst Oswaldo Cruz 100: 869-873. 
Gonzales MJ, Machekano RN, Shafer RW 2001. Human immunodeficiency virus type 1 reverse-transcriptase and protease subtypes: classification, amino acid mutation patterns, and prevalence in a northern California clinic-based population. J Infect Dis: 184: 998-1006.

Hanna GJ, D'Aquilla RT 1999. Antiretroviral drug resistance in HIV-1. Curr Infect Dis Rep 1: 289-297.

Hertogs K, Bloor S, Kemp SD, Van den Eynde C, Alcorn Tm, Pauwels R, Van Houte M, Staszewski S, Miller V, Larder BA 2000. Phenotypic and genotypic analysis of clinical HIV-1 isolates reveals extensive protease inhibitor crossresistance: a survey of over 6000 samples. AIDS 14: 12031210.

Hirsch MS, Brun-Vezinet F, Clotet B, Conway B, Kuritzkes DR, D'Aquila RT, Demeter LM, Hammer SM, Johnson VA, Loveday C, Mellors JW, Jacobsen DM, Richman DD 2003. Antiretroviral drug resistance testing in adults infected with human immunodeficiency virus type 1: 2003 recommendations of an International AIDS Society-USA Panel. Clin Infect Dis 37: 113-128.

Houtte MV, Lecocq P, Bacheler L 2003. Prevalence and quantitative phenotypic resistance patterns of specific nucleoside analogue mutation combinations and of mutations 44 and 118 in reverse transcriptase in a large dataset of recent HIV-1 clinical isolates. Antiviral Therapy 8: S242.

Janssen RS, Satlen GA, Stramer SL, Rawal BD, O’Brien TR, Weiblen BJ, Hecht FM, Jack N, Cleghon FR, Kahn JO, Chesney MA, Busch MP 1999. New testing strategy to detect early HIV-1 infection for use in incidence estimates and for clinical and prevention purposes. JAMA 281: 1893.

Little SJ, Holte S, Routy J, Daar ES, Markowitz M, Collier AC, Koup RA, Mellors JW, Connick E, Conway B, Kilby M, Wang L, Whitcomb JM, Hellman NS, Richman DD 2002. Antiretroviral drug resistance among patients recently infected with HIV. N Eng J Med 347: 385-394.

Marins JRP, Jamal LF, Chen SY, Barros, MB, Hudes ES, Barbosa AA, Chequer P, Teixeira, PR, Hearst N 2003. Dramatic improvement in survival among Brazilian AIDS patients. AIDS 17: 1675-1682.

Mocroft A, Ledergerber B, Katlama C, Kirk O, Reiss P, d'Arminio, Monforte A, Knysz B, Dietrich M, Phillips AN, Lundgren JD, EuroSIDA study group 2003. Decline in the AIDS and death rates in the Euro SIDA Study: an observational study. Lancet 362: 22-29.
Montes B, Segondy M 2002. Prevalence of mutational pattern $\mathrm{E} 44 \mathrm{D} / \mathrm{A}$ and/or V118I in the reverse transcriptase (RT) gene of HIV-1 in relation to treatment with nucleoside analogue RT inhibitors. J Med Virol 66: 299-303.

Novak RM, Chen L, MacArthur RD, Baxter JD, Huppler Hullsiek K, Peng G, Xiang Y, Henely C, Schmetter B, Uy J, van den Berg-Wolf M, Kozal M, Terry Beirn Community Programs for Clinical Research on AIDS 058 Study Team 2005. Prevalence of antiretroviral drug resistance mutations in chronically HIV-infected, treatment-naïve patients: implication for routine resistance screening before initiation of antiretroviral therapy. Clin Infect Dis 40: 468-474.

Palella Jr FJ, Delaney KM, Moorman AC 1998. Declining morbidity and mortality among patients with advanced human immunodeficiency virus infection. N Eng J Med 338: 853860.

Pao D, Andrady U, Clarke J, Dean G, Drake S, Fisher M, Green T, Kumar S, Murphy M, Tang A, White D, Underhill G, Pillay D, Cane P 2004. Long-term persistence of primary genotypic resistance after HIV-1 seroconversion. J Acquir Immune Defic Syndr 37: 1570-1573.

Pires IL, Soares MA, Speranza FAB, Ishii SK, Viera MCG, Gouvêa MIFS, Guimarães MAAM, Oliveira FE, Magnanini MMF, Brindeiro RM, Tanuri A 2004. Prevalence of human immunodeficiency virus drug resistance mutations and subtypes in drug-naïve, infected individuals in the army health service of Rio de Janeiro, Brazil. J Clin Microbiol 42: 426-430.

Rhee SY, Gonzales MJ, Kantor R, Betts BJ, Ravela J, Shafer RW 2003. Human immunodeficiency virus reverse transcriptase and protease sequence data. Nucleic Acids Res 31:298-303.

Soares MA, Brindeiro RM, Tanuri A 2004. Primary HIV-1 drug resistance in Brazil. AIDS 18 (Suppl. 3): S9-S13.

Stanford sequence resistance database 2005. Available at $<\mathrm{http}$ :/ /hivdb.stanford.edu> access 10 Nov 2005.

Tamalet C, Pasquier C, Yahi N, Colson P, Martin LP, Lepeu G 2000. Prevalence of drug resistant mutants and virological response to combination therapy in patients with primary HIV-1 infection. J Med Virol 61: 181-186.

Wu TD, Schiffer CA, Gonzales MJ, Taylor J, Kantor R, Chou S, Israelski D, Zolopa AR, Fessel WJ, Shafer RW 2003. Mutation patterns and structural correlates in human immunodeficiency virus type 1 protease following different protease inhibitor treatments. J Virol 77: 4836-4847. 